\title{
Displacement of aqua ligands from the hydroxopentaaquarhodium(III) ion by 1-hydroxybenzotriazole (HOBt): A kinetic and mechanistic approach
}

\author{
BIPLAB K BERA ${ }^{\mathrm{a}}$, ARUP MANDAL ${ }^{\mathrm{a}}$, BISWARUP MAITY ${ }^{\mathrm{b}}$, SUMON RAY $^{\mathrm{a}}$, \\ PARNAJYOTI KARMAKAR ${ }^{\mathrm{a}}$, SUBALA MONDAL ${ }^{\mathrm{a}}$, SUBHASIS MALLICK ${ }^{\mathrm{a}}$ \\ and ALAK K GHOSH ${ }^{\mathrm{a}, *}$

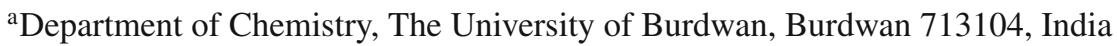 \\ ${ }^{b}$ Department of Chemistry, Chemgen Pharma International Pvt. Ltd., Block GP, Sector-V, Salt Lake City, \\ Kolkata 700091, India \\ e-mail: alakghosh2002@yahoo.co.in
}

MS received 28 August 2011; revised 27 March 2012; accepted 10 April 2012

\begin{abstract}
The kinetics of the reaction of $\mathrm{HOBt}$ with $\left[\mathrm{Rh}\left(\mathrm{H}_{2} \mathrm{O}\right)_{5}(\mathrm{OH})\right]^{2+}$ has been studied spectrophotometrically in aqueous medium as a function of $\left[\mathrm{Rh}\left(\mathrm{H}_{2} \mathrm{O}\right)_{5} \mathrm{OH}^{2+}\right],[\mathrm{HOBt}], \mathrm{pH}$ and temperature. At $\mathrm{pH} 4.3$, the reaction proceeds via a rapid outer sphere association complex formation step followed by two consecutive steps. The first of these involves ligand-assisted anation, while the second involves chelation as the second aqua ligand is displaced. The association equilibrium constant for the outer sphere complex formation has been evaluated together with the rate constants for the two subsequent steps. The activation parameters for both steps have been evaluated using Eyrings equation. Thermodynamic parameters calculated from the temperature dependence of the outer sphere association equilibrium constants are also consistent with an associative mode of activation. The product of the reaction has been characterized by IR and ESI-mass spectroscopic analysis.
\end{abstract}

Keywords. Kinetics; hydroxopentaaquarhodium(III); HOBt; mechanism; activation parameters.

\section{Introduction}

cis- $\mathrm{Pt}\left(\mathrm{NH}_{3}\right)_{2} \mathrm{Cl}_{2}$ (cisplatin) is well-known as an antitumour drug. ${ }^{1,2}$ However, there are still difficulties related to its use, because of numerous side effects and its toxicity. Several methods have been developed during the past ten years which have considerably reduced these side effects. Cisplatin is not very soluble in water and tends to hydrolyse at neutral $\mathrm{pH}$. Replacement of chloro ligands by carboxylate groups in carboplatin, ${ }^{3}$ cis-diammine(1,1-cyclobutanedicarboxylate)platinum(II), reduces the toxicity and increases the solubility in water. Among the platinum family elements, ruthenium has been successfully developed and tumor-inhibiting ruthenium complexes have been investigated in order to gain insight into their biological activities. ${ }^{4-10}$ The tumor inhibiting activities of ruthenium complexes, such as $\left[\mathrm{Ru}\left(\mathrm{NH}_{3}\right)_{3} \mathrm{Cl}_{3}\right]$, cis- $\left[\mathrm{Ru}\left(\mathrm{NH}_{3}\right)_{4} \mathrm{Cl}_{2}\right] \mathrm{Cl}$ or cis- $\left[\mathrm{RuCl}_{2}\left(\mathrm{Me}_{2} \mathrm{SO}\right)_{4}\right]$, have been known for quite some time. ${ }^{11}$ The complex

*For correspondence cis- $\left[\mathrm{Ru}^{\mathrm{II}} \mathrm{Cl}_{2}\left(\mathrm{Me}_{2} \mathrm{SO}\right)_{4}\right]$ presents lower toxicity ${ }^{12}$ than cisplatin and also, better antitumor activity in vivo (against Ehrlich ascites carcinoma, Lewis lung carcinoma, B16 melanoma, and MCa mammary carcinoma). Extensive studies on N-heterocyclic carbene (NHC) complexes in organometallic chemistry and catalysis has not yet studied. Only a restricted array of biomedical applications has been reported so far for silver, gold, palladium, copper, ruthenium, and rhodium derivatives, mainly for antimicrobial and antitumor purposes. ${ }^{13,14}$ Dimeric $\mu$-acetato complexes of rhodium(II) as well as monomeric square planar rhodium(I) and octahedral rhodium(III) complexes have shown interesting antitumor properties. ${ }^{15}$ Some rhodium(III) complexes are reported to have considerably greater cytostatic activity than cis-platin, ${ }^{16}$ particularly when their action against HCV29T tumor cells is considered. So far, rhodium and iridium complexes, analogs of the corresponding platinum compounds that possess significant antitumor properties, were found to be effective as anticancer agents, but some of them exhibited marked toxic effects. ${ }^{17,18}$ For certain ligands, the anation reaction follows Id path. A Ia path was proposed for the anation 
reaction of $\left[\mathrm{Rh}\left(\mathrm{H}_{2} \mathrm{O}\right)_{6}\right]^{3+}$ and $\left[\mathrm{Rh}\left(\mathrm{H}_{2} \mathrm{O}\right)_{5}(\mathrm{OH})\right]^{2+}$ by a variety of ligands. ${ }^{19-23}$

1-Hydroxybenzotriazole (HOBt) is an organic compound used as a racemization suppressor and to improve yield in peptide synthesis. ${ }^{24,25}$ In this paper, we report the interaction of HOBt with hydroxopentaaquarhodium(III) ion in aqueous medium and the possible mode of binding is discussed.

\section{Experimental}

\subsection{Materials}

$\left[\mathrm{Rh}\left(\mathrm{H}_{2} \mathrm{O}\right)_{6}\right]\left(\mathrm{ClO}_{4}\right)_{3}$ was prepared as per the literature method ${ }^{26}$ and characterized by chemical analysis and spectroscopic $\operatorname{data}^{27}\left(\lambda_{\max }=\right.$ $396 \mathrm{~nm}, \varepsilon=62 \mathrm{dm}^{3} \mathrm{~mol}^{-1} \mathrm{~cm}^{-1} ; \lambda_{\max }=311 \mathrm{~nm}$, $\left.\varepsilon=67.4 \mathrm{dm}^{3} \mathrm{~mol}^{-1} \mathrm{~cm}^{-1}\right)$. The reactant complex $\left[\mathrm{Rh}\left(\mathrm{H}_{2} \mathrm{O}\right)_{5}(\mathrm{OH})\right]\left(\mathrm{ClO}_{4}\right)_{2}$ (complex A) was obtained in situ (yield $\sim 90 \%$ ) by adjusting the $\mathrm{pH}$ to 4.3 . Higher proportions of complex could not be obtained as the solution becomes turbid at higher $\mathrm{pH}$. The reaction product of HOBt and complex A (complex C) was prepared by mixing them in different proportions namely $1: 1,1: 2,1: 3,1: 5$ and 1:10, and keeping the mixtures at $60^{\circ} \mathrm{C}$ for $72 \mathrm{~h}$. The absorption spectra of all the mixtures exhibited the same $\lambda_{\max }(338 \mathrm{~nm})$ with almost the same absorbances. The spectra of the product complex $\mathrm{C}$ and the reactant complex A are shown in figure 1.

\subsection{Product analysis}

The composition of the product in the reaction mixture was determined by Job's method of continuous variation (figure 2). The metal: ligand ratio was found to be $1: 1 .\left[\mathrm{Rh}\left(\mathrm{H}_{2} \mathrm{O}\right)_{5}(\mathrm{OH})\right]^{2+}$ and $\mathrm{HOBt}$ were therefore mixed in 1:1 molar ratio at $\mathrm{pH} 4.3$ and a yellow product was obtained on slow evaporation. The IR spectrum of the product as a $\mathrm{KBr}$ disc shows strong bands at $3417,1638 \mathrm{~cm}^{-1}$ and medium bands at 2927,2853 , 515 and $428 \mathrm{~cm}^{-1}$. The presence of a strong band at $\sim 3417 \mathrm{~cm}^{-1}$ indicates that the product contains aqua or hydroxyl ligands. The bands at $515 \mathrm{~cm}^{-1}$ and $428 \mathrm{~cm}^{-1}$ are assignable to the stretching of $\mathrm{Rh}-\mathrm{N}$ and $\mathrm{Rh}-\mathrm{O}$ bonds, respectively. ${ }^{28}$ The strong and broad band at $1638 \mathrm{~cm}^{-1}$ indicates that $-\mathrm{N}=\mathrm{N}$-group is metalated.

The aqueous solution of $\left[\mathrm{Rh}\left(\mathrm{H}_{2} \mathrm{O}\right)_{5}(\mathrm{OH})\right]^{2+}$ and HOBt were mixed in a 2:1 molar ratio and the mixture was thermostated at $60^{\circ} \mathrm{C}$ for 48 hours and used for ESIMS measurement. The ESI mass spectra of the resulting solution is shown in figure 3 .

It is clear from this spectrum that the ion peak at $\mathrm{m} / \mathrm{z}=190.04$ has become the precursor ion species in the mixture solution and this is attributed to

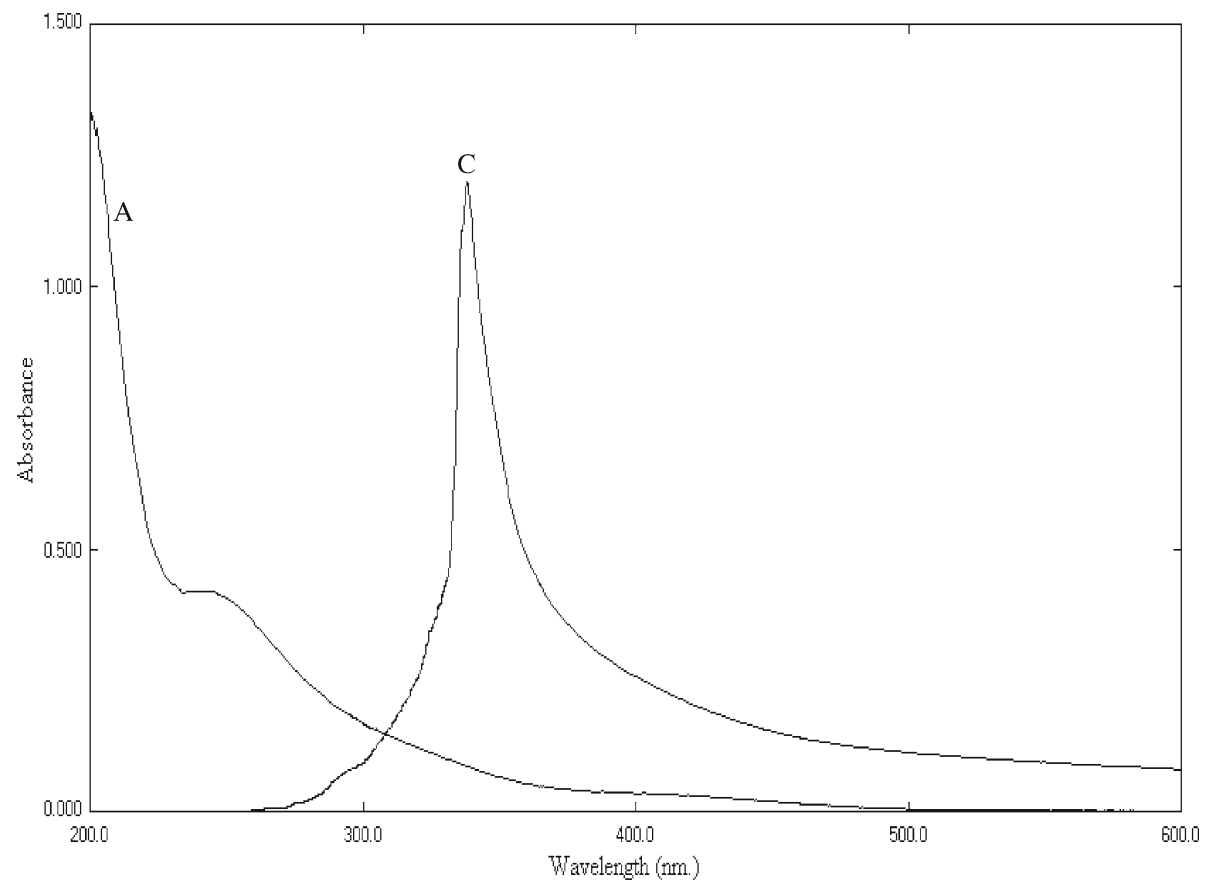

Figure 1. Spectral difference between reactant complex (A) and product complex $\mathrm{C}:(\mathrm{A})\left[\mathrm{Rh}\left(\mathrm{H}_{2} \mathrm{O}\right)_{5}(\mathrm{OH})\right]^{2+}=2.5 \times 10^{-4} \mathrm{~mol} \mathrm{dm}^{-3}(\mathrm{C})\left[\mathrm{Rh}\left(\mathrm{H}_{2} \mathrm{O}\right)_{5}(\mathrm{OH})\right]^{2+}=2.5 \times$ $10^{-4} \mathrm{~mol} \mathrm{dm}^{-3},[\mathrm{HOBt}]=7.5 \times 10^{-3} \mathrm{~mol} \mathrm{dm}^{-3}, \mathrm{pH}=4.3$, cell used $=1 \mathrm{~cm}$ quartz. 


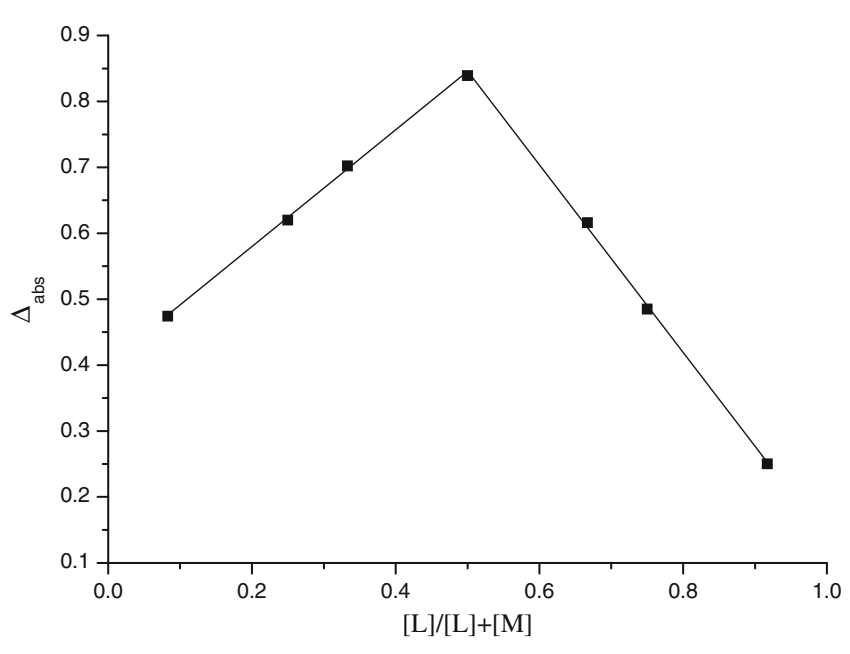

Figure 2. Job's plot for reaction of complex A with HOBt.

$\left(1 \mathrm{Rh}^{3+}+1 \mathrm{BtO}^{-}+7 \mathrm{H}_{2} \mathrm{O}+1 \mathrm{H}^{+}+1 \mathrm{HO}^{-}\right)^{2+}$. The precursor ion is shown in figure 4.

\subsection{Measurements}

All the spectra and kinetic measurements were recorded with a Shimadzu UV-VIS spectrophotometer (UV-2450 PC), attached to a thermoelectric cell temperature controller (model TCC-240A with an accuracy of $\left.+0.1^{\circ} \mathrm{C}\right)$. IR Spectra ( $\mathrm{KBr}$ disc, $4000-300 \mathrm{~cm}^{-1}$ ) were measured with a Perkin-Elmer FTIR model RX1 infrared spectrophotometer. ESI-mass spectra recorded using a micromass Q-Tof micro ${ }^{\mathrm{TM}}$ mass spectrometer in positive ion mode. The $\mathrm{pH}$ of the solutions was adjusted with $\mathrm{HClO}_{4} / \mathrm{NaOH}$ and measured with a Sartorius $\mathrm{pH}$ meter (model PB11) to an accuracy of \pm 0.01 .

The progress of the reaction was monitored by the absorbance measurements at different intervals of time with a Shimadzu spectrophotometer (UV-2450 PC) attached to a TCC-Controller (TCC-240A) at $338 \mathrm{~nm}$, where the spectral difference between the reactant and product complexes is maximum. Before each kinetic run the $\mathrm{pH}$ of each solution of reactant complex and the HOBt was adjusted to 4.3 and a pseudo-first order condition was maintained throughout. The plot of $\ln \left(\mathrm{A}_{\infty}\right.$ - $\mathrm{A}_{t}$ ) (where $\mathrm{A}_{t}$ and $\mathrm{A}_{\infty}$ are absorbances at time $\mathrm{t}$ and after completion of reaction) against time figure 5 were found to be nonlinear; being curved at the initial stage and subsequently linear, indicating that the reaction proceeds via two consecutive steps. From the limiting linear portion of the curve, the values of $\mathrm{k}_{2 \text { (obs) }}$ were obtained. The $\mathrm{k}_{1(\mathrm{obs})}$ values were obtained from the slope of $\ln \Delta$ versus time when $t$ is small (figure 6). The reported rate data represented as an average of duplicate runs were reproducible to within $\pm 4 \%$.

\section{Results and discussion}

HOBt has $\mathrm{pK}_{\mathrm{a}}$ value of 5.3 at $25^{\circ} \mathrm{C} .{ }^{29}$ The ionization of $\left[\mathrm{Rh}\left(\mathrm{H}_{2} \mathrm{O}\right)_{6}\right]^{3+}$ may be given as:

$$
\begin{gathered}
{\left[\mathrm{Rh}\left(\mathrm{H}_{2} \mathrm{O}\right)_{6}\right]^{3+}=\left[\mathrm{Rh}\left(\mathrm{H}_{2} \mathrm{O}\right)_{5} \mathrm{OH}\right]^{2+}+\mathrm{H}^{+}} \\
{\left[\mathrm{Rh}\left(\mathrm{H}_{2} \mathrm{O}\right)_{5} \mathrm{OH}\right]^{2+}=\left[\mathrm{Rh}\left(\mathrm{H}_{2} \mathrm{O}\right)_{4}(\mathrm{OH})_{2}\right]^{+}+\mathrm{H}^{+}}
\end{gathered}
$$

The $\mathrm{pK}_{\mathrm{c}(1)}$ and $\mathrm{pK}_{\mathrm{c}(2)}$ values of $\left[\mathrm{Rh}\left(\mathrm{H}_{2} \mathrm{O}\right)_{6}\right]^{3+}$ are 3.6 and 4.7 , respectively at $25^{\circ} \mathrm{C}$. ${ }^{30}$ Other reports on the $\mathrm{pK}_{\mathrm{c}(1)}$ value are 3.2, 3.4 and 3.45 (ref. 30). With increase in $\mathrm{pH}$, the proportion of the more labile hydroxopentaaquarhodium(III) ion increases. The hydroxide ligand increases the water exchange rate of $\left[\mathrm{Rh}\left(\mathrm{H}_{2} \mathrm{O}\right)_{5} \mathrm{OH}\right]^{2+}$ relative to $\left[\mathrm{Rh}\left(\mathrm{H}_{2} \mathrm{O}\right)_{6}\right]^{3+}$. In the $\mathrm{pH}$ range used in these

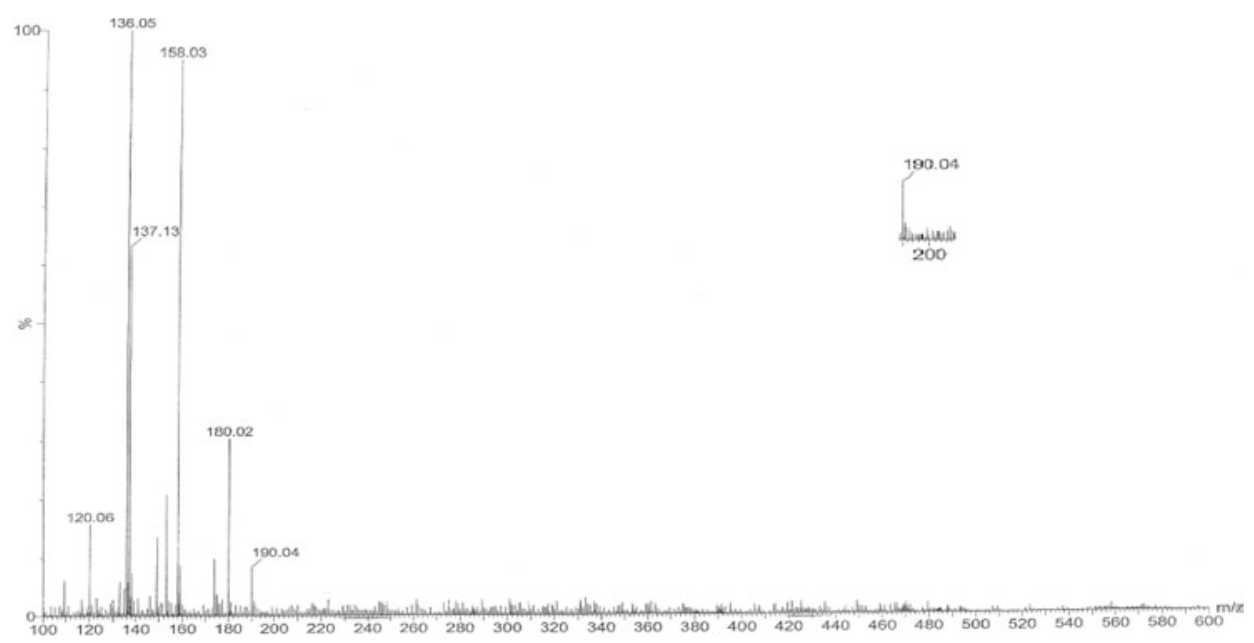

Figure 3. ESI-mass spectra of the product. 


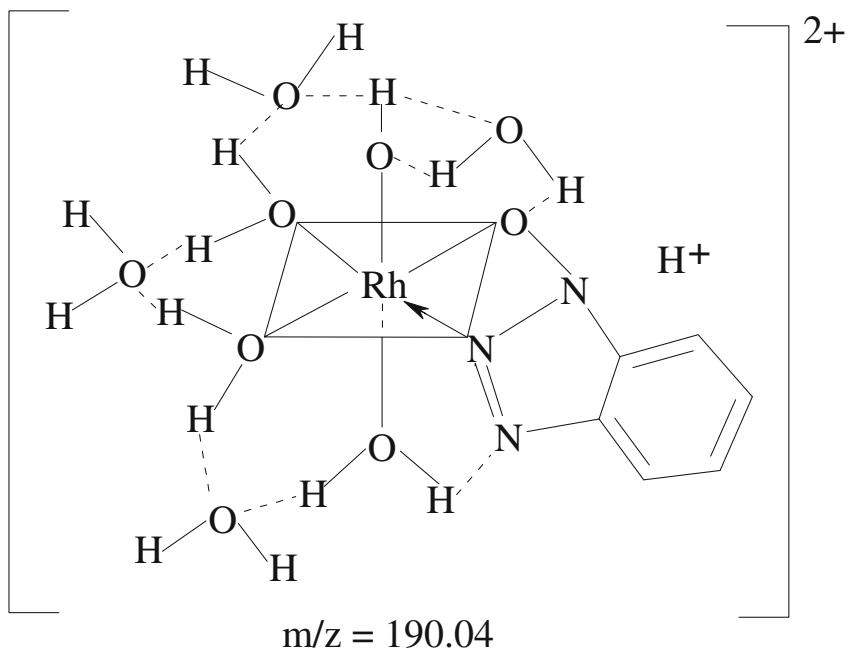

Figure 4. Plausible structure of the precursor ion peak from the ESI-mass spectra.

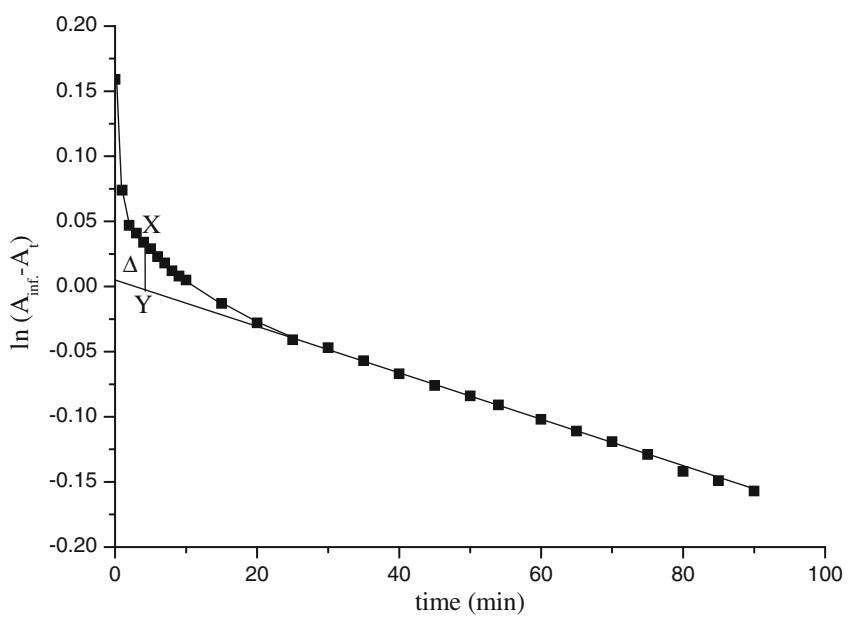

Figure 5. A plot of $\ln \left(\mathrm{A}_{\infty}-\mathrm{A}_{t}\right)$ versus time.

study, 1-hydroxybenzotriazole (HOBt) exists mainly as the HOBt. The $\mathrm{pH}$ range chosen in the present study is 3.0 to 4.3 , where the active species involved in the reaction is HOBt. At $\mathrm{pH}$ higher than 4.5, precipitation of $\mathrm{Rh}^{3+}$ takes place.

The title reaction may then be explained on the basis of scheme 1.

The rate constant for the first phase of the reaction $\mathrm{A} \rightarrow \mathrm{B}$ was calculated from the absorbance data using the Weyh and Hamm ${ }^{31}$ equation.

$$
\left(A_{\infty}-A_{t}\right)=a_{1} \exp \left(-k_{1(\text { obs })} t\right)+a_{2} \exp \left(-k_{2(\text { obs })} t\right)
$$

where $\mathrm{a}_{1}$ and $\mathrm{a}_{2}$ are constants that depend upon the rate constants and extinction coefficients.

Values of $\mathrm{a}_{2} \exp \left(-\mathrm{k}_{2(\mathrm{obs})} \mathrm{t}\right)$ at different times (when $t$ is small) were obtained from the linear portion

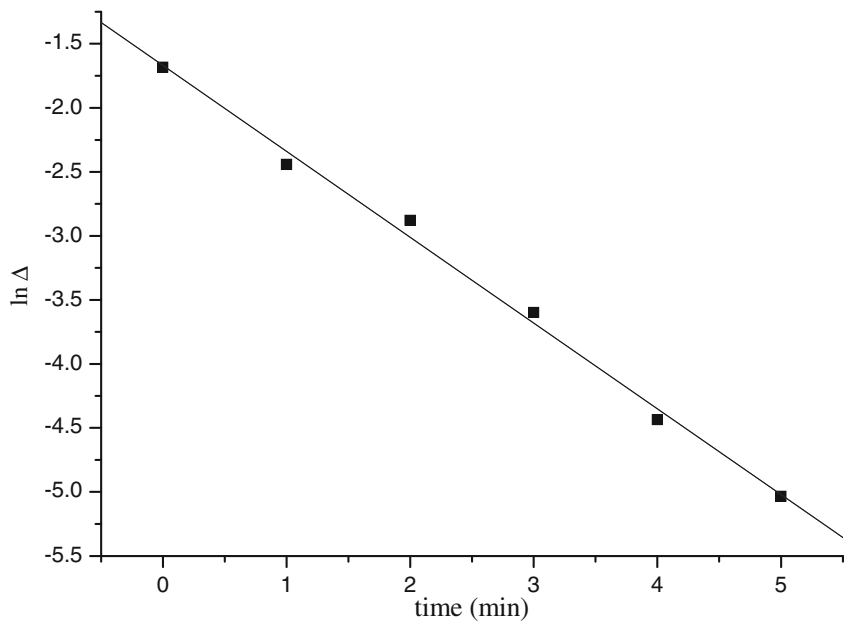

Figure 6. Plot of $\ln \Delta$ versus Time.

of the curve (figure 5) extended to $t$ equals zero, i.e.,

$$
a_{2} \exp \left(-k_{2(o b s)} t\right)=\left(A_{\infty}-A_{t}\right) \text { limiting. }
$$

Therefore, values of $\left(A_{\infty}-A_{t}\right)-a_{2} \exp \left(-k_{2(\text { obs })} t\right)$ were calculated from $\mathrm{X}$ and $\mathrm{Y}$ values (figure 5) at different $\mathrm{t} ; \Delta=\mathrm{a}_{1} \exp \left(-\mathrm{k}_{1(\mathrm{obs})} \mathrm{t}\right)$

$$
\text { or, } \ln \Delta=\text { constant }-\mathrm{k}_{1(\mathrm{obs})} \mathrm{t} \text {, }
$$

$\mathrm{k}_{1 \text { (obs) }}$ was then derived from the slope of $\ln \Delta$ versus time, for small values of $t$ (figure 6). A similar procedure was applied for each $\mathrm{HOBt}$ concentration in the $2.50 \times 10^{-3} \mathrm{~mol} \mathrm{dm}^{-3}$ to $7.50 \times 10^{-3} \mathrm{~mol} \mathrm{dm}^{-3}$ range using the experimental conditions specified in table 1 . The $\mathrm{k}_{1(\mathrm{obs})}$ values are presented in table 1 .

The rate increases with increase in [HOBt] and reaches a limiting value (figure 7). The limiting rate is probably due to the completion of outer sphere association complex formation. Since the metal ion reacts with its immediate environment, further change in [HOBt] beyond the saturation point will not affect the reaction rate. The outer sphere association complex may be stabilized through H-bonding. ${ }^{32,33}$ Based on the

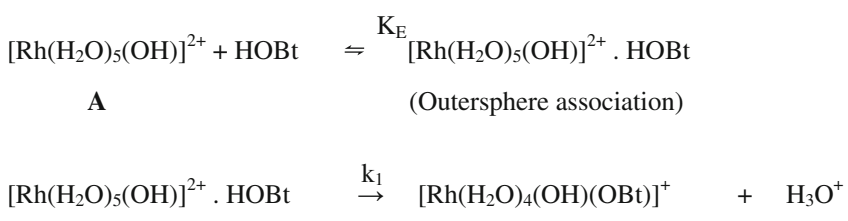
B $\left[\mathrm{Rh}\left(\mathrm{H}_{2} \mathrm{O}\right)_{4}(\mathrm{OH})(\mathrm{OBt})\right]^{+} \underset{\text { (chelation) }}{\stackrel{\mathrm{k}_{2}}{\rightarrow}}\left[\mathrm{Rh}\left(\mathrm{H}_{2} \mathrm{O}\right)_{3}(\mathrm{OH})(\mathrm{OBt})\right]^{+}+\mathrm{H}_{2} \mathrm{O}$

Scheme 1. Possible reaction pathways for the interaction of HOBt with the title complex. 
Table 1. $10^{3} \mathrm{k}_{1(\mathrm{obs})}$ and $10^{5} \mathrm{k}_{2(\mathrm{obs})}$ values for different $\mathrm{HOBt}$ concentrations at different temperatures; $\left[\right.$ Complex A] $=2.5 \times 10^{-4} \mathrm{~mol} \mathrm{dm}^{-3}, \mathrm{pH}=4.3$, ionic strength $=0.1 \mathrm{~mol} \mathrm{dm}^{-3} \mathrm{NaClO}_{4}$.

\begin{tabular}{|c|c|c|c|c|c|c|c|c|}
\hline \multirow[b]{2}{*}{$10^{3}$ [Ligand] $\left(\mathrm{mol} \mathrm{dm}^{-3}\right)$} & \multicolumn{4}{|c|}{$\begin{array}{c}10^{3} \mathrm{k}_{1(\mathrm{obs})} \\
\text { Temperature }\left({ }^{\circ} \mathrm{C}\right)\end{array}$} & \multicolumn{4}{|c|}{$\begin{array}{c}10^{5} \mathrm{k}_{2(\mathrm{obs})} \\
\text { Temperature }\left({ }^{\circ} \mathrm{C}\right)\end{array}$} \\
\hline & 50 & 55 & 60 & 65 & 50 & 55 & 60 & 65 \\
\hline 2.50 & 6.27 & 8.13 & 9.62 & 14.08 & 1.28 & 2.12 & 3.05 & 5.23 \\
\hline 3.75 & 7.39 & 9.80 & 11.90 & 16.42 & 1.28 & 2.13 & 3.05 & 5.23 \\
\hline 5.00 & 8.13 & 10.75 & 12.50 & 17.95 & 1.29 & 2.13 & 3.06 & 5.24 \\
\hline 6.25 & 8.58 & 11.33 & 13.69 & 19.62 & 1.29 & 2.14 & 3.07 & 5.25 \\
\hline 7.50 & 9.09 & 12.35 & 14.29 & 20.42 & 1.30 & 2.14 & 3.08 & 5.25 \\
\hline
\end{tabular}

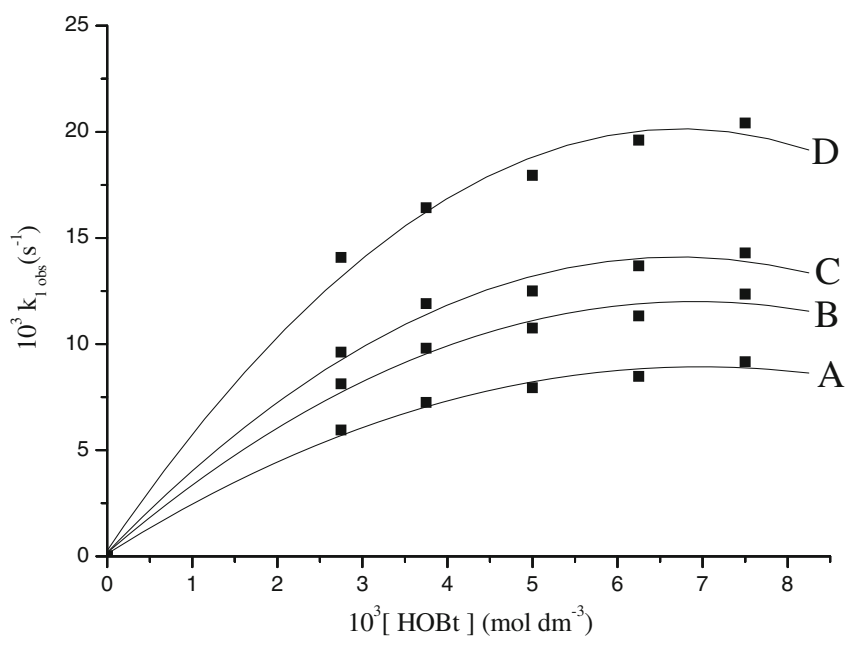

Figure 7. Plot of $\mathrm{k}_{1(\mathrm{obs})}$ versus $[\mathrm{HOBt}]$ at different temperature, $\mathrm{A}=50^{\circ} \mathrm{C}, \mathrm{B}=5^{\circ} \mathrm{C}, \mathrm{C}=60^{\circ} \mathrm{C}$ and $\mathrm{D}=65^{\circ} \mathrm{C}$.

\section{$\mathbf{A}+\mathrm{HOBt} \stackrel{\mathrm{K}_{\mathrm{E}}}{\rightleftharpoons} \mathbf{A} \cdot \mathrm{HOBt}$}

Outer sphere association complex

\section{$\mathbf{A} \cdot \mathrm{HOBt} \stackrel{\mathrm{k}_{1}}{\rightarrow} \mathbf{B}$}

Scheme 2. Possible reaction sequence for the interaction of $\mathrm{HOBt}$ with the title complex.

experimental findings, the scheme 2 may be proposed for the step $\mathbf{A} \rightarrow \mathbf{B}$;

Based on the above scheme, a rate expression can be derived for the $\mathbf{A} \rightarrow \mathbf{B}$ step

$$
\begin{gathered}
\left.\mathrm{d}[\mathrm{B}] / \mathrm{dt}=\mathrm{k}_{1} \mathrm{~K}_{\mathrm{E}}\left[\mathrm{Rh}\left(\mathrm{H}_{2} \mathrm{O}\right)_{5} \mathrm{OH}\right)\right]^{2+}[\mathrm{HOBt}] \\
\text { or, } \mathrm{d}[\mathrm{B}] / \mathrm{dt}=\mathrm{k}_{1(\text { obs })}\left[\mathrm{Rh}\left(\mathrm{H}_{2} \mathrm{O}\right)_{5}(\mathrm{OH})\right]_{\mathrm{T}}^{2+},
\end{gathered}
$$

where $\mathrm{T}$ stands for total concentration of $\mathrm{Rh}(\mathrm{III})$. We can then write

$$
\mathrm{k}_{1(\mathrm{obs})}=\mathrm{k}_{1} \mathrm{~K}_{\mathrm{E}}[\mathrm{HOBt}] /\left(1+\mathrm{K}_{\mathrm{E}}[\mathrm{HOBt}]\right),
$$

where $\mathrm{k}_{1}$ is the anation rate constant for the $\mathbf{A} \rightarrow \mathbf{B}$ step, i.e., the anation rate constant for the interchange of outer sphere complex to the inner sphere complex; $\mathrm{K}_{\mathrm{E}}$ is the outer sphere association equilibrium constant.

The equation can be represented as

$$
1 / \mathrm{k}_{1(\mathrm{obs})}=1 / \mathrm{k}_{1}+1 / \mathrm{k}_{1} \mathrm{~K}_{\mathrm{E}}[\mathrm{HOBt}] .
$$

The plot of $1 / \mathrm{k}_{1(\mathrm{obs})}$ against $1 /[\mathrm{HOBt}]$ should be linear with an intercept of $1 / \mathrm{k}_{1}$ and slope $1 / \mathrm{k}_{1} \mathrm{~K}_{\mathrm{E}}$. This was found to be the case at all temperatures studied. The $\mathrm{k}_{1}$ and $\mathrm{K}_{\mathrm{E}}$ values were calculated from the intercept and slope (figure 8) and are tabulated in table 2.

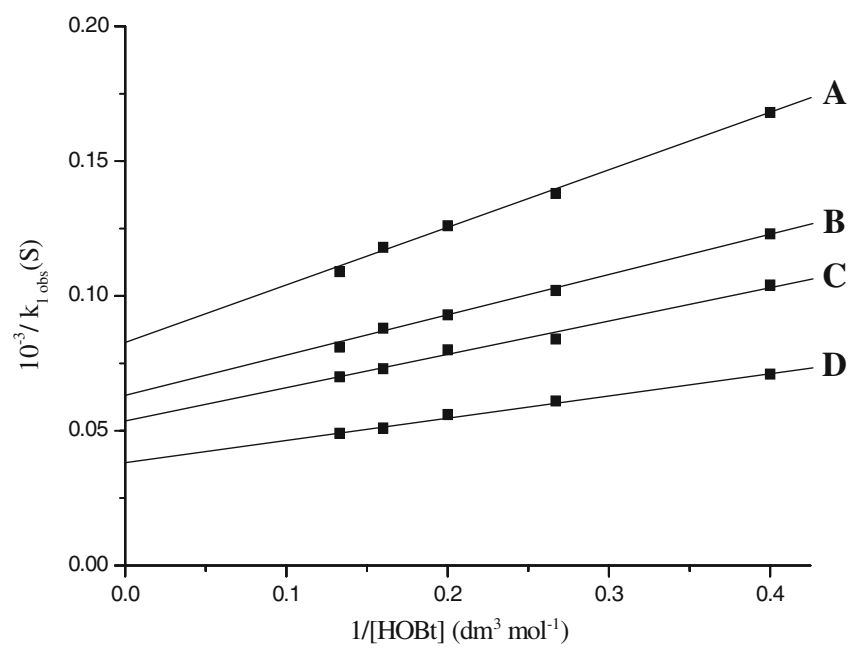

Figure 8. Plot of $1 / \mathrm{k}_{1(\mathrm{obs})}$ against $1 /[\mathrm{HOBt}], \mathrm{A}=50^{\circ} \mathrm{C}$, $\mathrm{B}=55^{\circ} \mathrm{C}, \mathrm{C}=60^{\circ} \mathrm{C}$ and $\mathrm{D}=65^{\circ} \mathrm{C}$.

Table 2. The $\mathrm{k}_{1}, \mathrm{k}_{2}$ and $\mathrm{K}_{\mathrm{E}}$ values for the substitution reaction.

\begin{tabular}{lccc} 
Temp. $\left({ }^{\circ} \mathrm{C}\right)$ & $10^{3} \mathrm{k}_{1}\left(\mathrm{~s}^{-1}\right)$ & $10^{5} \mathrm{k}_{2}\left(\mathrm{~s}^{-1}\right)$ & $\mathrm{K}_{\mathrm{E}}\left(\mathrm{dm}^{3} \mathrm{~mol}^{-1}\right)$ \\
\hline 50 & 12.18 & 1.29 & 383 \\
55 & 16.08 & 2.13 & 409 \\
60 & 18.77 & 3.06 & 428 \\
65 & 25.99 & 5.24 & 467 \\
\hline
\end{tabular}




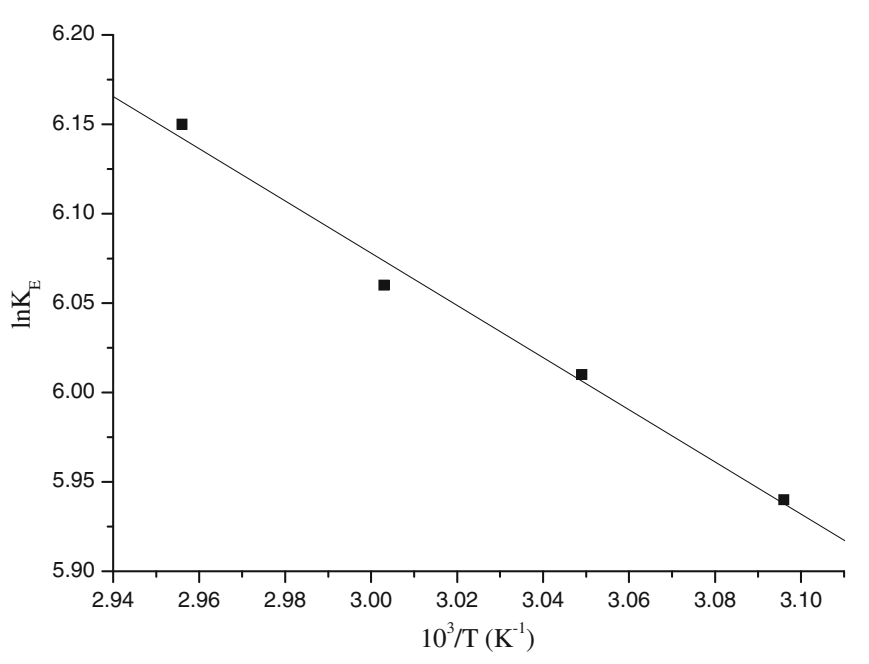

Figure 9. Plot of $\ln \mathrm{K}_{\mathrm{E}}$ versus $1 / \mathrm{T}$.

The second phase of the substitution reaction is the chelation step, to give complex $\mathrm{C}$ and is independent of HOBt concentration (figure 9). The $\mathrm{k}_{2(\mathrm{obs})}$ values were obtained directly from the limiting slopes of $\ln \left(\mathrm{A}_{\infty}-\mathrm{A}_{t}\right)$ versus $\mathrm{t}$ plots for different temperatures and are presented in table 2 .
Table 3. $10^{3} \mathrm{k}_{1(\mathrm{obs})}\left(\mathrm{s}^{-1}\right)$ and $10^{5} \mathrm{k}_{2(\mathrm{obs})}\left(\mathrm{s}^{-1}\right)$ values for anation of $\left[\mathrm{Rh}\left(\mathrm{H}_{2} \mathrm{O}\right)_{5}(\mathrm{OH})\right]^{2+}$ by $\mathrm{HOBt}$ at different $\mathrm{pH}$ values in aqueous solution; $[\mathrm{A}]=2.5 \times 10^{-4} \mathrm{~mol} \mathrm{dm}^{-3}$, [HOBt $]=$ $7.50 \times 10^{-3} \mathrm{~mol} \mathrm{dm}^{-3}$, temp. $=60^{\circ} \mathrm{C}$, ionic strength $=$ $0.1 \mathrm{~mol} \mathrm{dm}^{-3} \mathrm{NaClO}_{4}$.

\begin{tabular}{lcc}
\hline $\mathrm{pH}$ & $10^{3} \mathrm{k}_{1(\mathrm{obs})}\left(\mathrm{s}^{-1}\right)$ & $10^{5} \mathrm{k}_{2(\mathrm{obs})}\left(\mathrm{s}^{-1}\right)$ \\
\hline 3.0 & 5.32 & 1.79 \\
3.3 & 7.15 & 2.03 \\
3.6 & 8.73 & 2.45 \\
4.0 & 10.46 & 2.78 \\
4.3 & 14.29 & 3.08 \\
\hline
\end{tabular}

\subsection{Effect of $\mathrm{pH}$ on the reaction rate}

The reaction was studied at five different $\mathrm{pH}$ values (3.0, 3.3, 3.6, 4.0 and 4.3). The $\mathrm{k}_{o b s}$ values were found to increase with increase in $\mathrm{pH}$ in this range (table 3 ). The $\mathrm{k}_{\mathrm{obs}}$ values are given in table 3 . The enhancement in rate may be explained based on the acid dissociation equilibria of the reactants. The rate may be based on the equilibria of the reactants. A rate expression for path 1 may be given:

$$
\mathrm{k}_{(\mathrm{obs})}=\frac{\mathrm{k}_{1} \mathrm{~K}_{\mathrm{E}} \mathrm{K}_{\mathrm{c}(1)} \mathrm{K}_{\mathrm{a}}[\mathrm{HOBt}]_{\mathrm{t}}\left[\mathrm{H}^{+}\right]}{\left[\mathrm{H}^{+}\right]^{3}+\left[\mathrm{H}^{+}\right]^{2}\left(\mathrm{~K}_{\mathrm{a}}+\mathrm{K}_{\mathrm{c}(1)}\right)+\left[\mathrm{H}^{+}\right]\left(\mathrm{K}_{\mathrm{c}(1)} \mathrm{K}_{\mathrm{a}}+\mathrm{K}_{\mathrm{c}(1)} \mathrm{K}_{\mathrm{c}(2)}+\mathrm{K}_{\mathrm{c}(1)} \mathrm{K}_{\mathrm{a}} \mathrm{K}_{\mathrm{E}}[\mathrm{HOBt}]_{\mathrm{t}}\right)+\mathrm{K}_{\mathrm{c}(1)} \mathrm{K}_{\mathrm{c}(2)} \mathrm{K}_{\mathrm{a}}}
$$

where $\mathrm{k}_{1}$ and $\mathrm{K}_{\mathrm{E}}$ are rate constant and outer-sphere association equilibrium constant and also $\mathrm{K}_{\mathrm{c}(1)}, \mathrm{K}_{\mathrm{c}(2)}$ and $\mathrm{K}_{\mathrm{a}}$ are acid dissociation constants of $\left[\mathrm{Rh}\left(\mathrm{H}_{2} \mathrm{O}\right)_{6}\right]^{3+}$, $\left[\mathrm{Rh}\left(\mathrm{H}_{2} \mathrm{O}\right)_{4}(\mathrm{OH})\right]^{2+}$ and for the ligand $-\mathrm{OH}$ respectively.

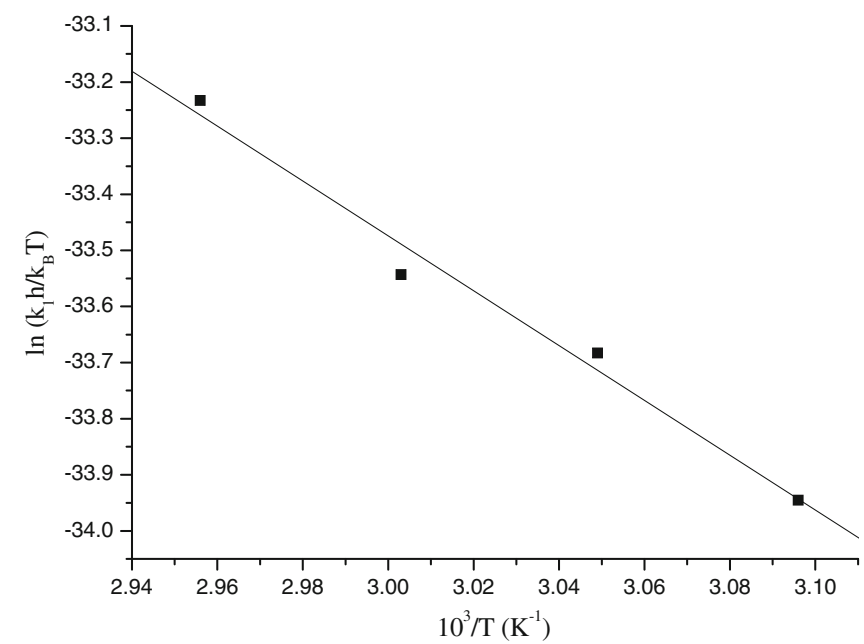

Figure 10. Eyring plot for $\mathrm{k}_{1}$.
Further study of the substitution reaction was followed at $\mathrm{pH} 4.3$ to avoid complications caused by adding an additional parameter $\left[\mathrm{H}^{+}\right]$to the rate equation. At $\mathrm{pH}$ 4.3 , the complex exists mainly in the hydroxopentaaqua

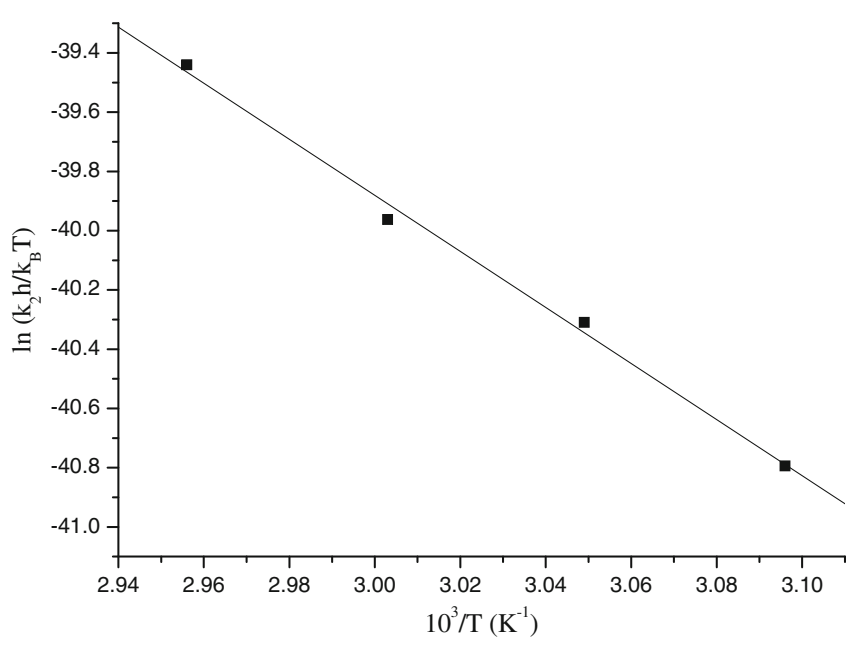

Figure 11. Eyring plot for $\mathrm{k}_{2}$. 
Table 4. Activation parameter of the anation reaction of $\left[\mathrm{Rh}\left(\mathrm{H}_{2} \mathrm{O}\right)_{5}(\mathrm{OH})\right]^{2+}$ with HOBt.

\begin{tabular}{lcccc}
\hline Ligand & $\Delta \mathrm{H}_{1}^{\neq}\left(\mathrm{kJmol}^{-1}\right)$ & $\Delta \mathrm{S}_{1}^{\neq}\left(\mathrm{JK}^{-1} \mathrm{~mol}^{-1}\right)$ & $\Delta \mathrm{H}_{2}^{\neq}\left(\mathrm{kJmol}^{-1}\right)$ & $\Delta \mathrm{S}_{2}^{\neq}\left(\mathrm{JK}^{-1} \mathrm{~mol}^{-1}\right)$ \\
\hline $\mathrm{HOBt}$ & $40.7 \pm 3.8$ & $-156 \pm 12$ & $78.7 \pm 3.8$ & $-95 \pm 12$ \\
\hline
\end{tabular}

form and the contribution due to the hexaaqua species is negligible.

With increase of $\mathrm{pH}$, the complex also changes from aqua to hydroxoaqua form and then the water exchange rate constant of $\left[\mathrm{Rh}\left(\mathrm{H}_{2} \mathrm{O}\right)_{5}(\mathrm{OH})\right]^{2+}$ increases relative to $\left[\mathrm{Rh}\left(\mathrm{H}_{2} \mathrm{O}\right)_{6}\right]^{3+}$.

\subsection{Effect of temperature on the reaction rate}

The reaction was studied at four different temperatures for different ligand concentrations and the results are listed in tables 1 and 2 . From the temperature dependence of the $K_{E}$ values (figure 9) $\Delta H^{\circ}$ and $\Delta S^{\circ}$ values are calculated to be $12.14 \pm 0.9 \mathrm{~kJ} \mathrm{~mol}^{-1}$ and $87 \pm 3 \mathrm{~J} \mathrm{~K}^{-1} \mathrm{~mol}^{-1}$, respectively. Thus from the thermodynamic consideration the negative $\Delta \mathrm{G}^{\circ}(-13.8$ $\mathrm{kJ} \mathrm{mol}^{-1}$ ) also supports the spontaneous formation of the outer sphere association complex. The activation parameters for both the steps $\mathbf{A} \rightarrow \mathbf{B}$ and $\mathbf{B} \rightarrow \mathbf{C}$ were evaluated from the linear Eyring plots (figures 10 and 11). The activation enthalpies and entropies are $\Delta \mathrm{H}_{1}^{\neq}=$ $40.7 \pm 3.8 \mathrm{~kJ} \mathrm{~mol}^{-1}, \Delta \mathrm{S}_{1}^{\neq}=-156 \pm 12 \mathrm{JK}^{-1} \mathrm{~mol}^{-1}$, $\Delta \mathrm{H}_{2}^{\neq}=78.7 \pm 3.8 \mathrm{~kJ} \mathrm{~mol}^{-1}, \Delta \mathrm{S}_{2}^{\neq}=-95 \pm 12 \mathrm{JK}^{-1}$ $\mathrm{mol}^{-1}$ (table 4). Further, from the temperature dependence of the $\mathrm{K}_{\mathrm{E}}$ values $\Delta \mathrm{H}^{\circ}$ and $\Delta \mathrm{S}^{\circ}$ values are calculated to be $12.14 \pm 0.9 \mathrm{~kJ} \mathrm{~mol}^{-1}$ and $87 \pm 3 \mathrm{~J}$ $\mathrm{K}^{-1} \mathrm{~mol}^{-1}$, respectively. Thus from the thermodynamic consideration the negative $\Delta \mathrm{G}^{\circ}\left(-13.8 \mathrm{~kJ} \mathrm{~mol}^{-1}\right)$ also supports the spontaneous formation of the outer sphere association complex.

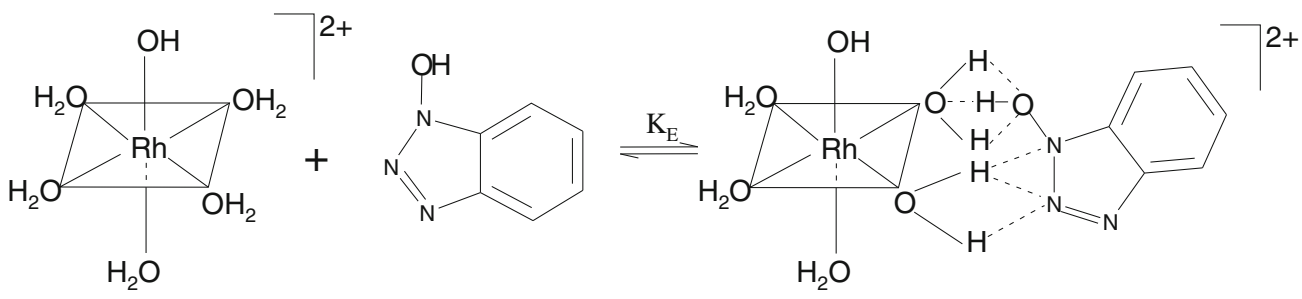

Complex (A) HOBt Outersphere association complex

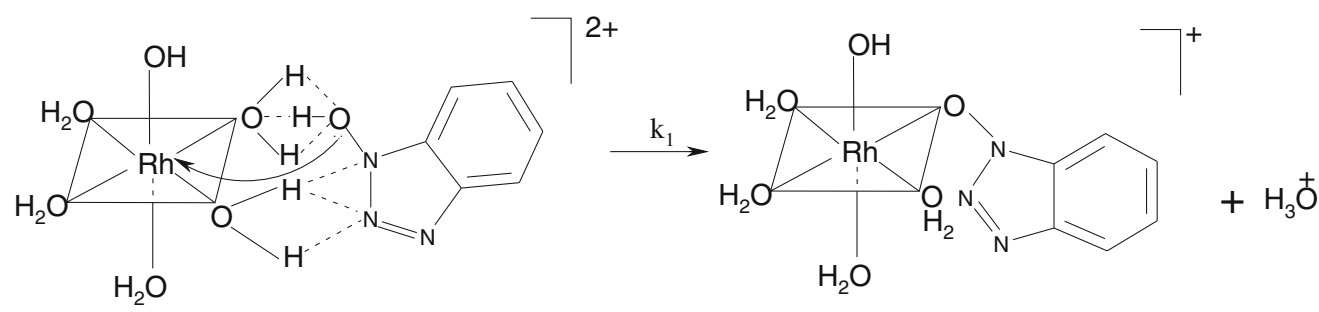

(B)

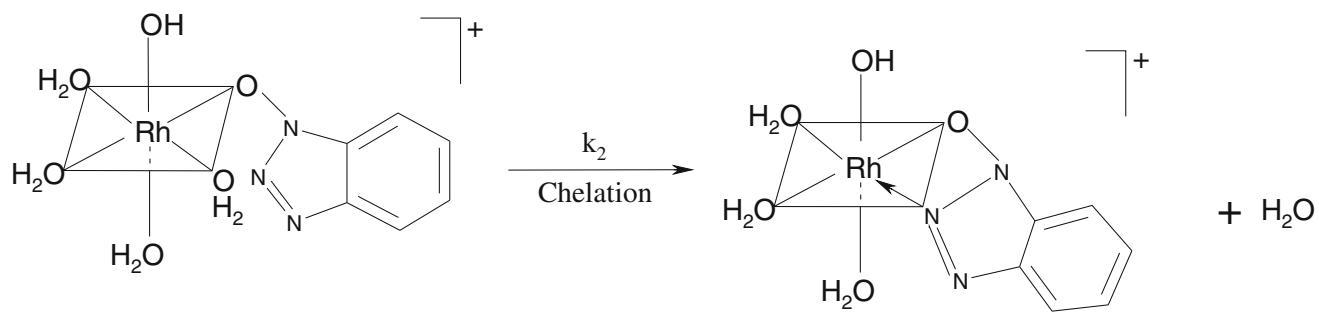

(C)

Figure 12. Plausible mechanism for the substitution of aqua ligands from $\left[\mathrm{Rh}\left(\mathrm{H}_{2} \mathrm{O}\right)_{5}(\mathrm{OH})\right]^{2+}$ by $\mathrm{HOBt}$. 
The low $\Delta \mathrm{H}^{\ddagger}$ values are in support of the ligand participation in the transition state for both the steps. The high negative $\Delta S^{\neq}$values suggest a more compact transition state, where both the incoming and departing ligands are attached in the transition state, than the starting complexes and this is also in support of the assumption of a ligand participated transition state.

\section{Mechanism}

The mechanism of substitution of aqua ligands in ion $\left[\mathrm{Rh}\left(\mathrm{H}_{2} \mathrm{O}\right)_{5}(\mathrm{OH})\right]^{2+}$ can be explained in terms of rapid outer sphere association complex formation, followed by two consecutive steps; the first is dependent of ligand concentration and second is the chelation i.e., ring closure step, which is independent of ligand concentration. At the experimental $\mathrm{pH} 4.3$ complex exists as hydroxoaqua species. At the outset of each step an outersphere association complex is formed, which is stabilized through H-bonding, this is followed by an interchange from outersphere to inner sphere complex. The outersphere association equilibrium constant, a measure of the extent of $\mathrm{H}$-bonding for each step at different temperatures are collected in table 2. From the temperature dependence of the $\mathrm{K}_{\mathrm{E}}$, the thermodynamic parameters calculated (figure 9) are: $\Delta \mathrm{H}^{\circ}=12.14 \pm$ $0.9 \mathrm{~kJ} \mathrm{~mol}^{-1}, \Delta \mathrm{S}^{\circ}=87 \pm 3 \mathrm{~J} \mathrm{~K}^{-1} \mathrm{~mol}^{-1}$. The negative $\Delta \mathrm{G}^{\circ}$ for the first equilibrium step also supports the spontaneous formation of an outer sphere association complex. The activation parameters $\left(\Delta \mathrm{H}_{1}^{\neq}=40.7 \pm\right.$ $\left.3.8 \mathrm{~kJ} \mathrm{~mol}^{-1}, \Delta \mathrm{S}_{1}^{\neq}=-156 \pm 12 \mathrm{JK}^{-1} \mathrm{~mol}^{-1}\right)$ for the first step and the second step $\left(\Delta \mathrm{H}_{2}^{\neq}=78.7 \pm 3.8 \mathrm{~kJ}\right.$ $\mathrm{mol}^{-1}, \Delta \mathrm{S}_{2}^{\neq}=-95 \pm 12 \mathrm{JK}^{-1} \mathrm{~mol}^{-1}$ ) suggest an associative mode of activation for the substitution process. The enthalpy of activation $\left(\Delta \mathrm{H}_{1}^{\neq}\right.$and $\left.\Delta \mathrm{H}_{2}^{\neq}\right)$values and negative $\left(\Delta S_{1}^{\neq}\right.$and $\left.\Delta S_{2}^{\neq}\right)$values implies a good degree of ligand participation in the transition state. The positive enthalpy change for breaking the $\mathrm{M}-\mathrm{OH}_{2}$ bond is partially compensated by the formation of M-L bond in the transition state. The participation of HOBt in the transition state results in a more compact state due to the low $\Delta \mathrm{H}^{\neq}$values and large negative $\Delta \mathrm{S}^{\neq}$values are obtained.

\section{Conclusion}

Based on the above facts, a plausible mechanism for the substitution has been proposed as shown (figure 12). The hydroxide group first attacks the $\mathrm{Rh}$ (III) center by the removal of a proton i.e., follows $\mathrm{k} 1$ path. Then the four-membered ring is completed by the ring $\mathrm{N}$ atom. As $\mathrm{Rh}(\mathrm{III})$ is the border-line metal ion, the possibility of $\mathrm{N}$ - coordination in the first step also cannot be ruled out. Then the monobonded species may undergo protolytic equilibrium (due to the pendent $-\mathrm{OH}$ functional group of the ligand) followed by chelation via rate determining process; it may involve competitive chelation by both pendent $-\mathrm{OH}$ and its dissociated $\left(-\mathrm{O}^{-}\right)$groups.

\section{References}

1. Rosenberg B and Vancamp L 1970 Cancer Res. 30 1799

2. Davidson J P, Faber P J, Fisher IV R G, Mansy S, Peresie H J, Rosenberg B and Vancamp A L 1975 Cancer Chemother. Pt. 1 59, 287

3. Roberts J J, Knox R J, Friedlos F and Lydall D A, in 1986 Biochemical mechanisms of platinum antitumour drugs. eds. D. C. H. Me Brien and T. F. Slater, Oxford: IRL Press, p. 29

4. Sava G and Bergamo A 2007 Dalton Trans. 13 1267

5. Groessl M, Reisner E, Hartinger C G, Eichinger $\mathrm{R}$, Semenova O, Timerbaev A R, Jakupec M A, Arion V B and Keppler B J 2007 Med. Chem. 50 2185

6. De Paula Q A, Batista A A, Nascimento O R, CostaFilho A J, Schultz M S, Bonfadini M R and Oliva G J 2000 Braz. Chem. Soc. 11530

7. Paula Q A, Batista A A, Castellano E E and Ellena J J 2002 Inorg. Biochem. 90144

8. Vock C A, Ang W H, Scolaro C, Phillips A D, Lagopoulos L, Juillerat-Jenneret L, Sava G, Scopelliti R and Dyson P J 2007 J. Med. Chem. 502166

9. Timerbaev A R, Hartinger C G, Aleksenko S S and Keppler B K 2006 Chem. Rev. 1062224

10. Alessio E 2004 Chem. Rev. 1044203

11. Pieper T, Borsky K, Keppler B K 1999 In: Clarke M J and Sadler P J (eds) Metallopharmaceuticals I-DNA interactions. Springer, Europe, London/UK, pp 171

12. Sava G, Giraldi T, Mestroni G and Zassinovich G 1983 Chem. Biol. Interact. 451

13. (a) Ray S, Mohan R, Singh J K, Samantaray M K, Shaikh M M, Panda D and Ghosh P 2007 J. Am. Chem. Soc. 129 15042; (b) Hickey J L, Ruhayel R A, Barnard P J, Baker M V, Berners-Price S J and Filipovska A 2008 J. Am. Chem. Soc. 130 12570; (c) Teyssot M-L, Jarrousse A-S, Chevry A, De Haze A, Beaudoin C, Manin M, Nolan S P, Diez-Gonzales S, Morel L and Gautier A 2009 Chem. Eur. J. 15314

14. Hindi K M, Panzner M J, Tessier C A, Cannon C L and Youngs W J 2009 Chem. Rev. 1093859

15. Katsaros N and Anagnostopoulou A 2002 Crit. Rev. Oncol. Hematol. 42297

16. Pruchnik F P, Jakimowicz P, Cuinik Z, Zakrzewskaczerwinska J, Opolski A, Weitrzyk J and Wojdat E 2002 Inorg.Chim. Acta. 33459

17. Medvetz D A, Stakleff K D, Schreiber T, Custer P D, Hindi K, Panzner M J, Blanco D D, Taschner M J, 
Tessier C A and Youngs W J 2007 J. Med. Chem. 50 1703

18. Loganathan D and Morrison 2006 Photochem. Photobiol. 82237

19. Swaminathan K and Harris G M 1996 J. Am. Chem. Soc. 884411

20. Buchacck R J and Harris G M 1976 Inorg. Chem. 15 926

21. Ghosh A K, Ghosh S and De G S 1996 Indian J. Chem. 35A 342

22. Ghosh A K, Sengupta P S and De G S 1997 Indian J. Chem. 36A 611

23. Mukhopadhyay S K, Ghosh A K and De G S 1999 Indian J. Chem. 38A 895

24. Sheehan J C and Hess G P 1955 J. Am. Chem. Soc. 77 1067

25. König W and Geiger R 1970 Chem. Ber. 103788
26. Ayres G H and Forrester J S 1957 J. Inorg. Nucl. Chem. 3365

27. Wolsey W C, Reynolds C A and Kleinberg J 1963 Inorg. Chem. 2463

28. Steel D and Verhoeven P F M 2001 Vibrational Spectroscopy 2529

29. Ohkubo A, Ezawa Y, Seio K and Sekine M 2002 Nucleic Acids Research Supplement No. 2, 29-30 Oxford University Press

30. Banyai I, Glaser J, Read M C and Stroem M S 1995 Inorg. Chem. 342423

31. Weyh J A and Hamm R E 1969 Inorg. Chem. 82298

32. Jeffrey G A 1997 An introduction to hydrogen bonding, Oxford: Oxford University Press

33. Desiraju G R and Steiner T T 1999 The weak hydrogen bonding in structural chemistry and biology, Oxford: Oxford University Press 